\title{
Gas Permeability of Fruit Coating Waxes
}

\author{
Robert D. Hagenmaier and Philip E. Shaw \\ U.S. Citrus and Subtropical Products Laboratory, Agricultural Research Service, U.S. Department \\ of Agriculture, P. O. Box 1909, Winter Haven, FL 33883
}

\begin{abstract}
Additional index words. $\mathbf{O}_{2}$, water vapor, $\mathrm{CO}_{2}$, ethylene, barrier, permeance
Abstract. The permeability to $\mathrm{O}_{2}, \mathrm{CO}_{2}, \mathrm{C}_{2} \mathrm{H}_{4}$, and water vapor was determined for 19 commercial fruit wax coatings, four ingredients thereof, and one shrink-wrap film. For the commercial coatings, the $\mathrm{O}_{2}$ permeability at $50 \%$ relative humidity and $30 \mathrm{C}$ ranged from 470 to $22,000 \mathrm{ml}(\mathrm{STP}) \times \mathrm{mil} /\left(\mathrm{m}^{2} \times\right.$ day $\left.\times \mathrm{atm}\right)(1 \mathrm{mil}=0.0254 \mathrm{~mm})$ with $\left.\mathrm{CO}\right)_{2}$ - permeability two to eight times as high. Permeability to noncondensable gases tended to be higher for coatings made from carnauba wax than for those made from shellac and rosin. Commercial fruit wax had sufficiently low noncondensable gas permeability to account for large reductions in the respiration rate of coated fruit. Wax coatings could be improved if permeability were controlled:
\end{abstract}

Coatings applied to the surfaces of fruits and vegetables are commonly called "waxes, whether or not any component thereof is actually a wax. Commodities that are waxed include apples, avocados, citrus, cucumbers, eggplant, peaches, sweet peppers, and tomatoes. Waxing improves appearance, but waxes are often selected with little consideration for other properties.

The extensive literature documents various properties that are altered by the waxing of fruits and vegetables. Hardenburg's bibliography (1967) covers 292 papers on waxing. Since then, further studies have described the effects of waxing on diverse crops.

Perhaps the most-studied property of waxed fruit is its weight loss during storage (Bramlage, 1986; Cohen et al., 1990; Cuquerella et al., 1981; Erbil and Muftugil, 1986; Farooqi et al., 1988; Hasegawa et al., 1981; Krishnamurthy and Kushalappa, 1985; Lidster, 1981; Paull and Chen, 1989; Purvis, 1983; Tewari et al., 1980; Wells, 1973). In almost all cases, waxed commodities lost weight more slowly than unwaxed controls. In fact, weight reduction has been recommended as a criterion of good waxing (Hall, 1981; Tugwell, 1980).

Waxing also has been studied in relation to spoilage, especially chilling injury and browning. In many of these cases, waxed fruit had less spoilage and a lower respiration rate than uncoated samples. Prevention of spoilage was sometimes attributed to adjuncts, such as fungicides or bioregulators, but more often to the diffusion barrier formed by the coating. The barrier hindered $\mathrm{O}_{2}$ and $\mathrm{CO}_{2}$ diffusion, thus reducing the respiration rate (Banks, 1984a, 1985; Erbil and Muftugil, 1986; Farooqi et al., 1988; Meheriuk and Porritt, 1972; Smith and Stow, 1984; Waks et al., 1985). Another benefit of waxing is retention of firmness. Waxed fruit was usually firmer than the controls. Coatings also prevent spoilage by serving as a barrier to water vapor (Grierson and Wardowski, 1978; Morris, 1982). The reduction in spoilage is of such significance that waxing is considered a cost-effective substitute where refrigerated storage is unaffordable (Dalal et al., 1971).

A principal disadvantage of wax coatings is the development of off-flavors from their use (Ben-Yehoshua, 1967; Chen and Paull, 1986; Cohen et al., 1990; Cuquerella et al., 1981; Dhalla

\footnotetext{
Received for publication 1 May 1991. Accepted for publication 15 Aug. 1991. Mention of a trademark or proprietary product is for identification only and does not imply a warranty or guarantee of the product by the U.S. Dept. of Agriculture over other products that may also be suitable. The cost of publishing this paper was defrayed in part by the payment of page charges. Under postal regulations, this paper therefore must be hereby marked advertisement solely to indicate this fact.
}

and Hanson, 1988; Erbil and Muftugil, 1986; Farooqi et al., 1988; Krishnamurthy and Kushalappa, 1985; Paull and Chen, 1989; Tewari et al., 1980). Adverse flavor changes have been attributed to the inhibition of $\mathrm{O}_{2}$ and $\mathrm{CO}_{2}$ exchange, thus resuiting in anaerobic respiration and elevated ethanol and acetaldehyde contents (Ahmad and Khan, 1987; Banks, 1984a; Cohen et al., 1990; Cuquerella et al., 1981; Drake et al., 1987; Nisperos-Carriedo et al., 1990; Risse et al., 1987).

In general, with the exceptions of appearance and lubrication (Lidster, 1981; Mellenthin et al., 1982), the literature shows that the effects of waxing are directly related to gas exchange between the fruit and its environment. However, the same literature provides no values for the permeability properties of fruit coatings except for a few estimates made from permeance of waxed vs. unwaxed fruits (Banks, 1984a; Ben-Yehosua et al., 1985; Paull and Chen, 1989) or based on relative values from storage of the same commodity with different coatings (BenYehosua, 1967; Cuquerella et al., 1981; Hasegawa et al., 1981; Namesny and Decoud, 1988; Rohrbach and Paull, 1982; Siade et al., 1977; Trout et al., 1953). Because of general lack of data on permeability, the considerable literature on coatings is of little value in predicting whether a coating used for one purpose is suitable for another.

We therefore determined values for permeability for some typical fruit wax coatings and components and attempted to show how a coating's permeability may be used to predict its performance.

\section{Materials and Methods}

Fick's law. Gas exchange between a plant and its environment is generally governed by Fick's law (Nobel, 1974), which states that flux of a gas or water vapor through a barrier varies with permeance $(\mathrm{P})$ and pressure gradient.

$$
\text { Flux }=\mathrm{P} x \text { [pressure difference] }
$$

Permeability is defined as

$$
\text { Permeability }=\mathrm{P} \boldsymbol{x} \text { thickness. }
$$

For barriers in series, such as a laminated film, the permeance through the series $(\mathrm{P}$,$) is related to the permeance of the peel$ $(\mathrm{P}$, and coating (PC) as follows (Crank, 1956):

$$
1 / \mathrm{P}_{\mathrm{s}}=1 / \mathrm{P}_{\mathrm{p}}+1 / \mathrm{P}_{\mathrm{c}} \text {. }
$$

American Society for Testing Materials-recommended metric

Abbreviations: RH, relative humidity; STP, standard temperature (0C) and pressure $(1 \mathrm{~atm})$ 
units for permeability are $\mathrm{ml}(\mathrm{STP}) \times \mathrm{mil} /\left(\mathrm{m}^{2} \times\right.$ day $\left.\times \mathrm{atm}\right)$ where $1 \mathrm{mil}$ is 0.001 inch $(0.0254 \mathrm{~mm})$. Corresponding units for permeance are $\mathrm{ml}(\mathrm{STP}) /\left(\mathrm{m}^{2} \times\right.$ day $\left.\times \mathrm{atm}\right)$, which are the units used for permeability of $\mathrm{O}_{2}, \mathrm{CO}_{2}$, and $\mathrm{C}_{2} \mathrm{H}_{4}$. The units for water vapor are $\mathrm{g} \mathrm{mil} / \mathrm{m}^{2} \cdot \mathrm{day}^{-1} \cdot \mathrm{mm}^{-1} \mathrm{Hg}$ for permeability and $\mathrm{g} \cdot \mathrm{m}^{-2} \cdot$ day $^{-1} \cdot \mathrm{mm}^{-1} \mathrm{Hg}$ for permeance. Nevertheless, for the calculation of the ratio of water vapor to $\mathrm{O}_{2}$ permeability (see Table 4), both first had to be converted to the same units. For that conversion, $1 \mathrm{~g} \mathrm{mil} / \mathrm{m}^{2} \cdot \mathrm{day}^{-1} \cdot \mathrm{mm}^{-1} \mathrm{Hg}$ is equivalent to $945,600 \mathrm{ml}(\mathrm{STP}) \times \mathrm{mil} /\left(\mathrm{m}^{2} \times\right.$ day $\left.\times \mathrm{atm}\right)$.

Waxes, Samples of commercial fruit waxes were obtained from American Machinery Corp., Orlando, Fla.; Brogdex Co., Pomona, Calif.; Bryler Creative Systems, Johnson Wax, Racine, Wis.; FMC Corp., Lakeland, Fla.; Fresh Mark Corp., Ocoee, Fla.; Inotek International Corp., Mentor, Ohio; and Pennwalt Corp., Decco Division, Monrovia, Calif. Wood rosin samples were from Brogdex Co. and Resinall, Hattiesburg, Miss., and carnauba wax emulsion was from American Machinery Corp. The shrink-wrap film was type D955, 60 gauge $(0.015 \mathrm{~mm})$ from Cryovac, Duncan, S.C. The formulations of the commercial waxes are proprietary, but available information is shown in Table 1. The 19 commercial wax coatings are samples A to $\mathrm{S}$; the other materials are samples 1 to 5 .

Permeability measurements. Permeability was measured by the method of Hagenmaier and Shaw (1991). The liquid coating was brushed onto plastic films of known high permeability; polyethylene-vinyl acetate film for $\mathrm{O}_{2}, \mathrm{CO}_{2}$, and $\mathrm{C}_{2} \mathrm{H}_{4}$ permeability; and cellulose acetate for water vapor. The films were cut into pieces to provide individual samples. The coating thickness for each sample was measured with a micrometer caliper and also calculated from the weight and density of the coating. A typical coating was $0.008 \mathrm{~mm}$ ( 0.3 roil) thick. Water vapor permeance of coated and uncoated samples was measured with the Permatran-W1A water vapor permeability tester (Modern Controls, Minneapolis). Films were mounted with the cellulose acetate on the side with $0 \%$ relative humidity (RH) and the coating on the side with saturated $\mathrm{NaCl}(75 \% \mathrm{RH})$ or $\mathrm{KNO}_{3}$ (92\% RH).

Permeabilities of $\mathrm{O}_{2}, \mathrm{CO}_{2}$, and $\mathrm{C}_{2} \mathrm{H}_{4}$ were all measured on the same samples. Oxygen permeability was determined with the Ox-tran 100 permeability tester (Modern Controls) calibrated with standard reference material 1470, a polyester film from National Bureau of Standards. Carbon dioxide and $\mathrm{C}_{2} \mathrm{H}_{4}$ permeability were determined simultaneously, using gas made up of $50 \%$ each. Concentrations of these two gases were measured with a gas chromatography (Hewlett-Packard Model 5890A) fitted with a $30 \mathrm{~m} \times 0.53 \mathrm{~mm}$ id. polystyrene (GSQ) column (J\&W Scientific, Folsom, Calif.) and a thermal conductivity detector. Column and detector temperature were 40 and 120C, respectively, and He carrier gas flow rate was $4.8 \mathrm{ml} \cdot \mathrm{min}^{-1}$. For standard reference material 1470 , the measured $\mathrm{CO}_{2}$ permeance was $11 \%$ below the certified value. For measurement of $\mathrm{O}_{2}, \mathrm{CO}_{2}$, and $\mathrm{C}_{2} \mathrm{H}_{4}$ permeabilities, $\mathrm{RH}$ was controlled to within five percentage points of the desired value by passing the incoming gases through bubblers kept at the appropriate wet bulb temperatures, and by using samples that had been conditioned beforehand in containers of controlled humidity. Coating permeability was calculated from the permeability of coated and uncoated films using Eqs. [1-3]. The reported permeability values, all measured at $30 \mathrm{C}$, are mean values from three samples.

\section{Results and Discussion}

Permeability to $\mathrm{O}_{2}, \mathrm{CO}_{2}$, and $\mathrm{C}_{2} \mathrm{H}_{4}$ For the noncondensable gases, permeability to $\mathrm{O}_{2}, \mathrm{CO}_{2}$, and $\mathrm{C}_{2} \mathrm{H}_{4}$ is generally lower for the coatings with shellac and rosin than with carnauba and other waxes (Table 2). This observation fits the findings of

Table 1. Characteristics of 19 commercial wax coatings, a shrink-wrap film, and four related coatings.

\begin{tabular}{|c|c|c|}
\hline $\begin{array}{l}\text { Sample } \\
\text { no. }\end{array}$ & Major ingredients & Recommended for \\
\hline A & Waxes, natural and synthetic, and fatty acids & Muskmelon and stonefruit \\
\hline B & Polyethylene and shellac & Lemon (for storage) \\
\hline $\mathrm{C}$ & Carnauba wax and fatty acids & Peach, plum, nectarine \\
\hline $\mathrm{D}$ & Carnauba wax and shellac & Pear, apple, citrus \\
\hline $\mathrm{E}$ & Shellac, carnauba, fatty acids & Apple \\
\hline $\mathrm{F}$ & Carnauba, fatty acids, shellac & Apple, pear, citrus \\
\hline $\mathrm{G}$ & Coumarone-indene resin ${ }^{2}$ & Citrus \\
\hline $\mathrm{H}$ & Rosin and carnauba & Citrus \\
\hline I & Hydrocarbon resins and fatty acids & Citrus \\
\hline $\mathrm{J}$ & Rosin, oleic acid, and shellac & Citrus \\
\hline K & Shellac and rosin & Citrus \\
\hline $\mathrm{L}$ & Shellac and fatty acids & Citrus \\
\hline M & Shellac and rosin & Citrus \\
\hline $\mathrm{N}$ & Carnauba, shellac, and rosin & Citrus \\
\hline $\mathrm{O}$ & Sucrose esters and carboxymethyl cellulose & $\begin{array}{l}\text { Apples, avocado, banana, lime, melon, plantain, } \\
\text { papaya, pear, pineapple, plum }\end{array}$ \\
\hline $\mathrm{P}$ & Shellac and rosin & Citrus \\
\hline Q & Shellac & Citrus \\
\hline $\mathrm{R}$ & Shellac, rosin, and morpholine & Citrus \\
\hline $\mathrm{s}$ & Shellac & Apple \\
\hline 1 & $\begin{array}{l}\text { Shrink-wrap film D955 (polyethylene-vinyl } \\
\text { acetate copolymer) }\end{array}$ & \\
\hline 2 & Carnauba wax, morpholine, and oleic acid & \\
\hline 3 & Rosin, oleic acid, and $\mathrm{NH}_{3}$ & \\
\hline 4 & Shellac and, morpholine & \\
\hline 5 & Modified maleic resin and morpholine & \\
\hline
\end{tabular}


Table 2. Permeability at $30 \mathrm{C}$ of 19 commercial wax coatings and five reference materials to $\mathrm{O}_{2}, \mathrm{CO}_{2}$, and $\mathrm{C}_{2} \mathrm{H}_{4}{ }^{2}{ }^{2}$

\begin{tabular}{|c|c|c|c|c|}
\hline $\begin{array}{l}\text { Sample } \\
\text { no. }\end{array}$ & $\begin{array}{c}\mathrm{CO}_{2} \\
50 \% \mathrm{RH}\end{array}$ & $\begin{array}{c}\mathrm{C}_{2} \mathrm{H}_{4} \\
50 \% \mathrm{RH}\end{array}$ & $\begin{array}{c}\mathrm{O}_{2} \\
50 \% \mathrm{RH}\end{array}$ & $\begin{array}{c}\mathrm{O}_{2} \\
85 \% \mathrm{RH}\end{array}$ \\
\hline A & $175,000^{y}$ & $88,000^{y}$ & $21,600^{y}$ & 19,000 \\
\hline B & 37,000 & 17,000 & 11,200 & $7,400^{x}$ \\
\hline $\mathrm{C}$ & 49,000 & 14,000 & 10,300 & $8 ; 500$ \\
\hline $\mathrm{D}$ & 16,000 & 7,400 & 4,400 & $3,200^{x}$ \\
\hline$E$ & 14,000 & 5,000 & 4,300 & $2,900^{x}$ \\
\hline$F$ & 9,800 & 3,100 & 2,700 & 2,700 \\
\hline $\mathrm{G}$ & 7,600 & 940 & 2,600 & 2,100 \\
\hline $\mathrm{H}$ & 7,200 & 930 & 2,300 & $1,600^{x}$ \\
\hline$I$ & 4,600 & 670 & 2,200 & $680^{x}$ \\
\hline $\mathbf{J}$ & 3,600 & 450 & 2,000 & $880^{x}$ \\
\hline $\mathrm{K}$ & 3,800 & 610 & 1,700 & 1,300 \\
\hline L & 3,500 & 360 & 1,000 & 1,100 \\
\hline $\mathrm{M}$ & 2,600 & 270 & 1,000 & 830 \\
\hline $\mathrm{N}$ & 2,800 & 400 & 1,000 & $700^{x}$ \\
\hline 0 & 4,500 & 1,980 & 800 & 1,000 \\
\hline $\mathrm{P}$ & 1,800 & 180 & 730 & 740 \\
\hline $\mathrm{Q}$ & 1,900 & 170 & 640 & 770 \\
\hline $\mathrm{R}$ & 1,700 & 140 & 550 & 440 \\
\hline $\mathrm{S}$ & 1,700 & 180 & 470 & $750^{x}$ \\
\hline 1 & 27,000 & 12,000 & 9,100 & 8,900 \\
\hline 2 & 7,800 & 3,200 & 2,000 & 1,500 \\
\hline 3 & 2,200 & 170 & 780 & $1,100^{x}$ \\
\hline 4 & 1,100 & 90 & 370 & 430 \\
\hline 5 & 910 & 310 & 250 & $490^{x}$ \\
\hline
\end{tabular}

${ }^{2}$ Permeability expressed as $\mathrm{ml}(\mathrm{STP}) \times \mathrm{mil} /\left(\mathrm{m}^{2} \times\right.$ day $\times$ atm $)$.

${ }^{y}$ Coefficient of variation is $10 \%$.

${ }^{x}$ Oxygen permeability significantly different $(P £ 0.05)$ at $\mathrm{RH}$ of $50 \%$ and $85 \%$.

Ashley (1985), who notes that polymers containing hydroxy, ester, and other polar groups tend to have a lower $\mathrm{O}_{2}$ permeability than polymers with hydrocarbon and other nonpolar groups. The $\mathrm{O}_{2}$ content is $23 \%$ for shellac (Martin, 1982); » $8 \%$ to $20 \%$ for rosin, depending on the modification (Noller, 1965); $6 \%$ for carnauba wax (Bennet, 1975); and $<5 \%$ for polyethylene wax (Food and Drug Administration, 1990).

Because of equipment limitations, the permeabilities were measured at $30 \mathrm{C}$ rather than at the temperatures used for refrigerated fruit storage. At lower temperatures the permeability is less, as has been shown by Rij and Mackey (1986) for plastic films. Shellac coatings at $0 \mathrm{C}$ have $\mathrm{O}_{2}$ permeability an order of magnitude less than at 30C (Hagenmaier and Shaw, 1991).

RH also has an important effect on permeability. Some of the coatings have significantly different values of $\mathrm{O}_{2}$ permeability at $50 \%$ and $85 \%$ RH (Student's $t$ test, Table 2). This RH dependence is in large part due to the polar components used to raise $\mathrm{pH}$ and solubilize the polymer. For example, shellac solubilized with $\mathrm{NaOH}$ is much more permeable to $\mathrm{O}_{2}$ than that solubilized with morpholine, especially above $85 \% \mathrm{RH}$ (Hagenmaier and Shaw, 1991). Thus, at the high values of RH best suited for fruit storage, the permeability can be much higher than those given in Table 2 .

Water vapor. Under the conditions of measurement, there was less variation in permeability to water vapor (Table 3 ) than to the other gases (Table 2). Still, the commercial waxes exhibit a 17-fold difference in water vapor permeability. As shown previously (Hagenmaier and Shaw, 1991) permeability to water vapor can be even more sensitive to RH than permeability to $\mathrm{O}_{2}$, especially for a wax that contains polar ingredients.

Permeability of coated fruit. Consider the model where the
Table 3. Water vapor permeability at 30C of 19 commercial wax coatings and five reference materials at $75 \%$ or $92 \% \mathrm{RH}$ on the coated side of the film.

\begin{tabular}{lcc}
\hline \hline Sample & $75 \% \mathrm{RH}$ & $92 \% \mathrm{RH}$ \\
no. & 1.1 & $0.86^{\mathrm{y}}$ \\
\hline $\mathrm{A}$ & 3.4 & $4.5^{\mathrm{y}}$ \\
$\mathrm{B}$ & 18 & 14 \\
$\mathrm{C}$ & 1.3 & 0.8 \\
$\mathrm{D}$ & 2.9 & 3.1 \\
$\mathrm{E}$ & 4.3 & $2.3^{\mathrm{y}}$ \\
$\mathrm{F}$ & 1.3 & 1.5 \\
$\mathrm{G}$ & 3.2 & 3.0 \\
$\mathrm{H}$ & 3.9 & $11^{\mathrm{y}}$ \\
$\mathrm{I}$ & 2.7 & $4.5^{\mathrm{y}}$ \\
$\mathrm{J}$ & 2.2 & $3.6^{\mathrm{y}}$ \\
$\mathrm{K}$ & 7.2 & $8.7^{\mathrm{y}}$ \\
$\mathrm{L}$ & 4.7 & $14.3^{\mathrm{y}}$ \\
$\mathrm{M}$ & 3.2 & $10^{\mathrm{y}}$ \\
$\mathrm{N}$ & 9.7 & 8.7 \\
$\mathrm{O}$ & 4.7 & $11^{\mathrm{y}}$ \\
$\mathrm{P}$ & $5.8^{\mathrm{y}}$ \\
$\mathrm{Q}$ & 5.0 & $12^{\mathrm{y}}$ \\
$\mathrm{R}$ & 5.3 & 9.6 \\
$\mathrm{~S}$ & 9.1 & 0.22 \\
1 & 0.20 & $0.6^{\mathrm{y}}$ \\
2 & 0.8 & $30^{\mathrm{y}}$ \\
3 & 1.7 & $19^{\mathrm{y}}$ \\
4 & 4.4 & $3.6^{\mathrm{y}}$ \\
5 & 2.5 & \\
\hline
\end{tabular}

'Permeability expressed as $\mathrm{g} \mathrm{mil} / \mathrm{m}^{2} \cdot \mathrm{day}^{-1} \cdot \mathrm{mm}^{-1} \mathrm{Hg}$. The mean coefficient of variation is $10 \%$.

"Permeabilities significantly different $(P £ 0.05)$ at $\mathrm{RH}$ of $75 \%$ and $92 \%$.

only pathway for gas exchange of an uncoated fruit is by active permeation through the fruit skin rather than by diffusion through open stomata. Now consider the same fruit with a coating. The peel and coating form a barrier equivalent to a laminate film. Thus, the permeance of the coated fruit relates to permeance of fruit and coating according to Eq. [3].

For example, an uncoated nonrefrigerated orange weighs 170 $\mathrm{g}$, has $150 \mathrm{~cm}^{2}$ of surface area, an internal partial $\mathrm{O}_{2}$ pressure of $18 \%$, and a respiration rate of $11 \mathrm{ml} \cdot \mathrm{kg}^{-1} \cdot \mathrm{h}^{-1}$ (Ben-Yehoshua et al., 1985; Eaks and Ludi, 1960; Davis and Hofmann, 1973; Vines et al., 1968). From Eq. [1], the permeance of the peel is $100,000 \mathrm{ml}(\mathrm{STP}) /\left(\mathrm{m}^{2} \times\right.$ day $\left.\times \mathrm{atm}\right)$. Now consider the same fruit coated with a 0.05 -roil-thick coating $(0.0013 \mathrm{~mm})$ having an $0_{2}$ permeability of $2000 \mathrm{ml}(\mathrm{STP}) \times \mathrm{mil} /\left(\mathrm{m}^{2} \times\right.$ day $x$ atm), a typical value for commercial coatings (Table 2). The permeance of the coating, from Eq. [2], is $40,000 \mathrm{ml}$ (STP)/ $\left(\mathrm{m}^{2} \times\right.$ day $\left.\times \mathrm{atm}\right)$. The permeance of the coated fruit, from Eq. [3], is $29,000 \mathrm{ml}(\mathrm{STP}) /\left(\mathrm{m}^{2} \times\right.$ day $\times$ atm $)$. Thus, permeance could be reduced from 90,000 to $28,000 \mathrm{ml}(\mathrm{STP}) /\left(\mathrm{m}^{2} \times\right.$ day $\times$ atm) by application of a coating to the fruit model. Alterations in gas exchange of the same magnitude have been observed from coating of nonrefrigerated real fruit (Banks, 1984a; Ben-Yehosua et al., 1985; Meheriuk and Porritt, 1972; Trout et al., 1953; Vines et al., 1968). Thus, the permeation model described and the $0_{2}$ permeability data of coatings maybe useful in predicting the gas-exchange behavior of coated fruits and vegetables.

Relative permeability. Table 4 shows how permeability values are related to one another at $30 \mathrm{C}$. As observed with polymers (Ashley, 1975), the ratios of noncondensable permeabilities 
Table 4. Permeability of $\mathrm{CO}_{2}$ and water vapor relative to that of $\mathrm{O}_{2}$ for 19 commercial wax coatings and five reference materials.

\begin{tabular}{|c|c|c|c|c|}
\hline \multirow{2}{*}{$\begin{array}{l}\text { Sample } \\
\text { no. }\end{array}$} & \multicolumn{2}{|c|}{$\mathrm{CO}_{2}$} & \multicolumn{2}{|c|}{ Water vapor } \\
\hline & Ratioy & $\mathrm{SE}^{\mathrm{X}}$ & Ratio $^{y}$ & $\mathrm{SE}^{\mathbf{X}}$ \\
\hline $\bar{A}$ & 8.1 & 2.1 & 38 & 4 \\
\hline B & 3.3 & 0.5 & 380 & 22 \\
\hline $\mathrm{C}$ & 4.8 & 0.5 & 1,300 & 230 \\
\hline D & 3.6 & 0.3 & 160 & 12 \\
\hline $\mathrm{E}$ & 3.2 & 0.7 & 660 & 34 \\
\hline $\mathrm{F}$ & 3.6 & 0.5 & 800 & 130 \\
\hline G & 2.9 & 0.4 & 550 & 50 \\
\hline $\mathrm{H}$ & 3.1 & 0.3 & 1,200 & 90 \\
\hline$\dot{I}$ & 2.0 & 0.5 & 4,500 & 1,400 \\
\hline $\mathbf{J}$ & 1.9 & 0.5 & 2,200 & 470 \\
\hline $\mathrm{K}$ & 2.3 & 0.3 & 2,100 & 200 \\
\hline $\mathrm{L}$ & 3.4 & 0.5 & 8,000 & 700 \\
\hline $\mathrm{M}$ & 2.5 & 0.2 & 13,000 & 2,800 \\
\hline $\mathbf{N}$ & 2.7 & 0.2 & 9,300 & 1,500 \\
\hline 0 & 5.6 & 0.5 & 10,000 & 1,200 \\
\hline $\mathbf{P}$ & 2.4 & 0.8 & 14,000 & 2,600 \\
\hline$Q$ & 3.0 & 0.4 & 8,500 & 760 \\
\hline $\mathbf{R}$ & 3.1 & 1.6 & 21,000 & 6,200 \\
\hline$S$ & 3.7 & 0.4 & 20,000 & 1,900 \\
\hline 1 & 3.1 & 0.1 & 24 & 1 \\
\hline 2 & 3.8 & 1.6 & 290 & 50 \\
\hline 3 & 2.9 & 1.0 & 37,000 & 11,000 \\
\hline 4 & 3.0 & 0.7 & 48,000 & 4,500 \\
\hline 5 & 3.7 & 0.7 & 14,000 & 2,900 \\
\hline
\end{tabular}

${ }^{2}$ Oxygen and $\mathrm{CO}_{2}$ permeability at $50 \% \mathrm{RH}$, water vapor permeability at $92 \% \mathrm{RH}$ on the coated side of the film.

${ }^{y}$ The $\mathrm{CO}_{2}$ or water vapor permeability divided by $0_{2}$ permeability.

${ }^{\mathrm{x}}$ The SE of the ratio was calculated from the variances and means of numerator and denominator.

vary much less than the permeabilities themselves. For fruit inside a continuous barrier of known permeability it follows from Eq. [1] that:

$$
\mathrm{PCO}_{2} / \mathrm{P}^{\mathrm{O}_{2}}=\left(20.9-\mathrm{O}_{2}{ }^{\mathrm{i}}\right) /\left(\mathrm{CO}_{2}{ }^{\mathrm{i}}-0.03\right) / R . Q .
$$

where R.Q. is the respiratory quotient $\left(\mathrm{O}_{2}\right.$ flux $/ \mathrm{CO}_{2}$ flux $) ; 20.9$ and 0.03 are ambient $\mathrm{O}_{2}$ and $\mathrm{CO}_{2}$ percentages, respectively, and $\mathrm{PO}_{2}$ and $\mathrm{PCO}_{2}$ are the $\mathrm{O}_{2}$ and $\mathrm{CO}_{2}$ permeances of the barrier.

A different treatment is appropriate when the main pathway for gas exchange is not by permeation but rather by diffusion through stomatal pores and the stem scar (Banks, 1984a, 1984b; Ben-Yehosua et al., 1985; Bramlage, 1986; Burg, 1990; Clendenning, 1941; Meheriuk and Lau, 1988). In the case where the only pathway is by diffusion, the flux is proportional to the diffusion constant in air, which for $\mathrm{CO}_{2}$ is 0.8 times that of $\mathrm{O}_{2}$ (Burg, 1990; Nobel, 1974). Since 0.8 is much lower than any of the $\mathrm{CO}_{2}$ ratios for fruit waxes (Table 2), calculation should permit some conclusions about the pathway for gas exchange in the coated fruit, which is related to the continuity of the coating. In the past, such analyses have been hampered by lack of information on permeability of the coating (Banks, 1984a; Ben-Yehoshua et al., 1985).

Ethylene. Ethylene permeability is important for diffusion of this gas into or out of the fruit. Unless it can permeate through the coating, it will accumulate inside the fruit and may adversely affect fruit quality, much as it does in a closed storage space (Knee, 1990; Watada, 1986). Diffusion of $\mathrm{C}_{2} \mathrm{H}_{4}$ into the fruit is important in degreening, but a wax barrier slows down the process (Jahn, 1976; Vakis, 1975). In both cases, highC ${ }_{2} \mathrm{H}_{4}$ permeability is desirable, which is best achieved with coatings made from waxes with little shellac or rosin (Tables 1 and 2).

Seal-wrapped fruit. Permeability measurements help to explain differences between seal-wrapped and coated fruit. The seal-wrap film had a very low permeability for water vapor and a relatively high one for $\mathrm{O}_{2}$ and $\mathrm{CO}_{2}$ compared to the fruit waxes (Tables 2 and 3). Seal-wrapped fruit has reduced transpiration and elevated respiration compared to fruit coated with coumarone-indene resin (Ben-Yehoshua et al., 1985; Hale et al., 1982; purvis, 1983).

Improvement of coatings. Wax coatings for citrus fruit differ markedly, thus some do not have the optimum permeabilities for the purpose intended. Permeability for citrus coatings should be high for $\mathrm{O}_{2}, \mathrm{CO}_{2}$, and $\mathrm{C}_{2} \mathrm{H}_{4}$ and low for water vapor to reduce transpiration as much as possible and not overly restrict respiration.

Permeability control may lead to a general improvement in the technology of fruit coatings. First, data are needed on the performance of coatings of known permeability and thickness. Much of the work done on performance of coatings cannot be used: commercial coating formulations change often, and therefore a coating's name is not sufficient identity. Moreover, thickness of coating has almost never been reported. Second, information is needed on what coating permeance is optimum for storage of various commodities. Finally, coatings need to be manufactured and used according to the permeability specifications. A similar approach was used for the plastic film that forms a permeability barrier for seal-wrapped fruit and vegetables (Daun et al., 1973; Gates, 1988).

\section{Literature Cited}

Ahmad, A. and I. Khan. 1987. Effect of waxing and cellophane lining on chemical quality indices of citrus fruit. Plant Foods for Human Nutr. 37:47-57.

Ashley, R.J. 1985. Permeability and plastics packaging, p. 269-308. In: J. Comyn (cd.). Polymer permeability. Elsevier, New York.

Banks, N.H. 1984a. Some effects of TAL Pro-long coating on ripening bananas. J. Expt. Bet. 35:127-137.

Banks, N.H. 1984b. Studies of the banana fruit surface in relation to the effects of TAL Pro-long coating on gaseous exchange. Sci. Hort. 24:279-286.

Banks, N.H. 1985. Internal atmosphere modification in Pro-long coated apples. Acts Hort. 157:105-112.

Bennet, H. 1975. Industrial waxes. vol. 1. Chemical Publ., New York.

Ben-Yehoshua, S. 1967. Some physiological effects of various skin coatings on orange fruit. Israel J. Agr. Res. 17(1):17-27.

Ben-Yehoshua, S., S.P. Burg, and R. Young. 1985. Resistance of citrus fruit to mass transport of water vapor and other gases. Physiol. Plant. 79:1048-1053.

Bramlage, W.J. 1986. Physiological effects of waxing on apples. New England Fruit Mtg. Proc. 92:111-113.

Burg, S.P. 1990. Theory and practice of hypobaric storage, p. 354372. In: M. Calderon and R. Barkai-Golan (eds.). Preservation by modified atmospheres. CRC Press, Boca Raton, Fla.

Chen, N.M. and R.E. Paull 1986. Development and prevention of chilling injury in papaya fruit. J. Amer. Soc. Hort. Sci. 111:639643.

Clendenning, K.A. 1941. Studies of the tomato in relation to its storage. Can. J. Res. 19:500-518.

Cohen, E., Y. Shalom, and I. Rosenberger. 1990. Postharvest ethanol buildup and off-flavor in 'Murcot' tangerine fruits. J. Amer. Soc. Hort. Sci. 115:775-778.

Crank, J. 1956. The mathematics of diffusion. Oxford University Press, London.

Cuquerella, J., J.M. Martinez-Javega, and M. Jimenez-Cuesta. 1981. Some physiological effects of different wax treatments on Spanish 
citrus fruit during cold storage. Proc. Intl. Soc. Citricult. 2:734737.

Dalal, V.B., W.E. Eipeson, and N.S. Singh. 1971. Wax emulsion for fresh fruits and vegetables to extend their storage life. Indian Food Packer 25(5):9-15.

Daun, H., S.G. Gilbert, Y. Ashkenazi, and Y. Henig. 1973. Storage quality of bananas packaged in selected permeability films. J. Food Sci. 38:1247-1250.

Davis, P.L. and R.C. Hofmann. 1973. Effects of coatings on weight loss and ethanol buildup in juice of oranges. J. Agr. Food Chem. 21(3):455-458

Dhalla, R. and S.W. Hanson. 1988. Effect of permeable coatings on the storage life of fruits. II Pro-long treatment of mangoes. Intl. J. Food Sci. Technol. 23:107-112.

Drake, S.R., J.K. Fellman, and J.W. Nelson. 1987. Postharvest use of sucrose polyesters for extending the shelf-life of stored 'Golden Delicious' apples. J. Food Sci. 52:1283-1285.

Eaks, I.L. and W.A. Ludi. 1960. Effects of temperature, washing, and waxing on the composition of the internal atmosphere of orange fruits. Proc. Amer. Soc. Hort. Sci. 76:220-228.

Erbil, H.Y. and N. Muftugil. 1986. Lengthening the postharvest life of peaches by coating with hydrophobic emulsions. J. Food Proc. Preserv. 10:269-279.

Farooqi, W.A., M. Salih Aahmad, and Zain-Ul-Abdin. 1988. Effect of wax-coatings on the physiological and bio-chemical aspects of 'Kinnow' fruit. Pakistan J. Sci. Industrial Res. 31:142-145.

Food and Drug Administration. 1990. Code of federal regulations. 21 CFR 172.260. Govt. Printing Office, Washington, D.C.

Gates, R. 1988. Extending fruit \& vegetable shelf life via permeable films. Food Eng. 60(2):3941.

Grierson, W. and W.F. Wardowski. 1978. Relative humidity effects on the postharvest life of fruits and vegetables. HortScience 15:570574.

Hagenmaier, R. and P.E. Shaw. 1991. The permeability of shellac coatings to water vapor and other gases. J. Agr. Food Chem. 39(5):825-829.

Hale, P.W., P.L. Davis, F.J. Marousky, and A.J. Bongers. 1982. Evaluation of a heat-shrinkable polymer film to maintain quality of Florida grapefruit during export. 1982. Citrus \& Veg. Msg. 46(10):3947.

Hall, D.J. 1981. Innovations in citrus waxing-An overview. Proc. Fla. State Hort. Soc. 94:258-263.

Hardenburg, R.E. 1967. Wax and related coatings for horticultural products-A bibliography. U.S. Dept. Agr., Agr. Res. Serv. 5115.

Hasegawa, Y., Y. Ishida, and Y. Iba. 1981. The effects of coatings with wax on citrus fruit II. The effects of coatings with various waxes on the quality of Kawano-Natsudaidai. Bul. Fruit Tree Res. Sta. B. 8:55-67.

Jahn, O.L. 1976. Degreening of waxed citrus fruit with ethephon and temperature. J. Amer. Soc. Hort. Sci. 101:597-599.

Knee, M. 1990. Ethylene effects in controlled atmosphere storage of horticultural crops, p. 225-235. In: M. Calderon and R. BarkaiGolan (eds.). Food preservation by modified atmospheres. CRC Press, Boca Raton, Fla.

Krishnamurthy, S. and C.G. Kushalappa. 1985. Studies on the shelf life and quality of Robusta bananas as affected by post-harvest treatments. J. Hort. Sci. Ashford, 60:549-556.

Lidster, P.D. 1981. Some effects of emulsifiable coatings on weight loss, stem discoloration, and surface damage disorders in 'Van' sweet cherries. J. Amer. Soc. Hort. Sci. 106:478-480.

Martin, J. 1982. Shellac. vol. 20. Kirk-Othmer encyclopedia of chemical technology. p. 737-747.

Meheriuk, M. and O.L. Lau. 1988. Effect of two polymeric coatings on fruit quality of 'Bartlett' and 'd'Anjou' pears. J. Amer. Soc. Hort. Sci. 113:222-226.

Meheriuk, M. and S.W. Porritt. 1972. Effects of waxing on respiration, ethylene production, and other physical and chemical changes in selected apple cultivars. Can. J. Plant Sci. 52:245-259.

Mellenthin, W.M., P.M. Chen, and D.M. Borgic. 1982. In-line application of porous wax coating materials to reduce friction discoloration of 'Bartlett' and 'd'Anjou' pears. HortScience 12:215-217.

Morris, L.L. 1982. Chilling injury of horticultural crops: An overview. HortScience 17:161-164.

Namesny, C. and A. Pablo Decoud. 1988. Evaluation of commercial citrus waxes. Proc. Sixth Intl. Citrus Congr., Balaban Publ., Philadelphia. p. 1505.

Nisperos-Carriedo, M.O., P.E. Shaw, and E.A. Baldwin. 1990. Changes in volatile flavor components of pineapple orange juice as influenced by application of lipid and composite films. J. Agr. Food Chem. 38:1382-1387.

Nobel, P.S. 1974. Biophysical plant physiology. W.H. Freeman, San Francisco.

Noller, C.R. 1965. Chemistry of organic compounds. W.B. Saunders, Philadelphia.

Paull, R.E. and N.J. Chen. 1989. Waxing and plastic wraps influence water loss from papaya fruit during storage and ripening. J. Amer. Soc. Hort. Sci. 114:937-942.

Purvis, A.C. 1983. Effects of film thickness and storage temperature on water loss and internal quality of seal-packaged grapefruit. J. Amer. Soc. Hort. Sci. 108:562-566.

Rij, R.E. and B. Mackey. 1986. Transmission rates of $\mathrm{CO}_{2}$ at $0^{\circ}, 10^{\circ}$, or $20^{\circ} \mathrm{C}$ through flexible films used for marketing fruits and vegetables. HortScience 23:836. (Abstr.)

Risse, L.A., D. Chun, R.E. McDonald, and W.R. Miller. 1987. Volatile production and decay during storage of cucumbers waxed, imazalil-treated, and film-wrapped. HortScience 22:274-276.

Rohrbach, K.G. and R.E. Paull. 1982. Incidence and severity of chilling induced internal browning of waxed 'Smooth Cayenne' pineapple. J. Amer. Soc. Hort. Sci. 107:453-457.

Siade, G., E. Pedraza, and F. de Quimica. 1977. Extension of storage life of banana (giant cavendish) using natural wax candelilla. Acts Hort. 16:327-334.

Smith, S.M. and J.R. Stow. 1984. The potential of a sucrose ester coating material for improving the storage and shelf-life qualities of Cox's Orange Pippin apples. Ann. Applied Biol. 104:383-391.

Tewari, J.D., N. Pandey, R.M. Rai, and C.B. Ram. 1980. Effect of wax emulsion on physiological factors influencing the storage behavior of Red Delicious apples. Indian J. Plant Physiol. (New Delhi) 23:257-265.

Trout, S.A., E.G. Hall, and S.M. Sykes. 1953. Effects of skin coatings on the behavior of apples in storage. I. Physiological and general investigations. Austral. J. Agr. Res. 4:57-81.

Tugwell, B.L. 1980. Assessment of citrus waxes. Report 9/80 South Australian Dept. Agr., Plant. Ind. Div. 5.

Vakis, N.J. 1975. Effects of ethephon and waxing on the degreening of Cyprus-grown lemons and grapefruit. J. Hort. Sci. 50:311-319.

Vines, H.M., W. Grierson, and G.J. Edwards. 1968. Respiration, internal atmosphere and ethylene evolution of citrus fruit. Proc. Amer. Soc. Hort. Sci. 92:227-234.

Waks, J., M. Schiffmann-Nates, E. Lomaniec, and E. Chalutz. 1985. Relation between fruit waxing and development of rots in citrus fruit during storage. Plant Dis. 69:869-870.

Watada, A.E. 1986. Effects of ethylene on the quality of fruits and vegetables. Food Technol. 40:82-85.

Wells, J.M. 1973. Postharvest wax-fungicide treatments of nectarines, peaches and plums for: reducing decay, reducing moisture loss, enhancing external appearance. U.S. Dept. Agr., Mktg. Res. Rpt. 981. 